\title{
Exploring the Impact of Innovativeness of Hospitality Service Operation on Customer Satisfaction
}

\author{
Ngan T. Truong \\ School of Business and Management, \\ RMIT University, 702 Nguyen Van Linh, Ho Chi Minh City, Vietnam \\ E-mail: s3653104@rmit.edu.vn (Corresponding Author) \\ Duy Dang-Pham \\ School of Science and Technology, \\ RMIT University, 702 Nguyen Van Linh, Ho Chi Minh City, Vietnam \\ E-mail: duy.dangphamthien@ rmit.edu.vn \\ Robert McClelland \\ School of Business and Management, \\ RMIT University, 702 Nguyen Van Linh, Ho Chi Minh City, Vietnam \\ E-mail: robert.mcclelland@ rmit.edu.vn

\section{Mathews Nkhoma} \\ School of Business and Management, \\ RMIT University, 702 Nguyen Van Linh, Ho Chi Minh City, Vietnam \\ E-mail: mathews.nkhoma@rmit.edu.vn
}

\begin{abstract}
Service Innovation is critical for service improvement and development that enhance customer satisfaction. Besides the importance of technology and tangible products, innovativeness leverages customer satisfaction by stimulating their five senses perception. Service-Dominant Logic emphasises the role of innovativeness in service delivery in alignment with customer perception to create Service Innovation. In other words, innovativeness involves the innovative service clues that drive customer perception when experiencing the intangible values of the operation. Despite the importance of innovativeness, studies for the issue appear to be limited and are especially scarce on qualitative research technique. Thus, this study aims to explore the impact of innovativeness on customer satisfaction in the case of hotel operations as qualitative research. A set of propositions are generated based on relevant works of literature and an approximate of one thousand reviews on the TripAdvisor website. The reviewers were international customers of 20 boutique hotels in Vietnam. The thematic analysis with deductive approach was employed to determine the key themes of Innovativeness that influence customer satisfaction. The findings suggest a conceptual model about the influences of 1) Innovative Humanic Clues, 2) Innovative Mechanic Clues and 3) Innovative Functional Clues on the customer's Transaction-Specific Satisfaction. The model explains how customers perceive innovativeness through the five senses and their evaluation on the innovativeness of the operations. The study, therefore, addresses the importance of innovativeness in service operation management to satisfy customer expectation for a new experience.
\end{abstract}

Keywords: service innovation, innovativeness, service-dominant logic, transaction-specific satisfaction, qualitative research technique, boutique hotel.

\section{INTRODUCTION}

Service innovation has increasingly gained attention from practitioners and scholars as the mean to develop new services. Service innovation is also critical to satisfying customer expectation for new experiences. Studies have focused on the application of technological products in service operations to leverage customer satisfaction (Morrar 2014; Stanko et al. 2014; Wuenderlich et al. 2015; Kuo et al. 2017; Zhang and Hou 2017). Research also discussed how customers accepted technological and digital applications in service operations (Kattara and El-Said 2014; Durst et al. 2015; Rosenbaum and Wong 2015). According to ServiceDominant Logic, customers not only experience the product or service but also assessing the process of encountering with the services (Lusch and Nambisan 2015). From this perspective, customers perceive the innovation and evaluate the innovativeness of service operations; they play as stakeholders in creating service innovation. Thus, operational performance for mutual benefits between customers and the operations can be optimised (Lusch and Nambisan 2015). Besides, gaining customer feedback about the clues of innovative clues is important to understand customer perception and evaluation of innovativeness of service operations (Ordanini et al. 2014; Rosenbaum and Wong 2015). This paper proposes a conceptual model that explains the impacts of innovative service clues and 
customer evaluation on the innovativeness of operation, which subsequently lead to behavioural intentions. We developed the proposed conceptual model based on relevant works of literature and the thematic analysis of reviews' content of customers on TripAdvisor about the innovativeness of boutique hotel operations.

Service operations in the hospitality industry focus on delivering the distinctiveness and pure hospitableness to customers. Hospitality operations that create positive emotions to customers with well-being values, as well as cultural and natural values, are considered as innovation (Jones et al. 2013). The boutique hotel sector can be considered as an example that responds to the call (Ahmad et al. 2017). However, very limited studies have investigated about this hotel concept (Ahmad et al. 2017; Hussein et al. 2018). Therefore, this paper also aims to explore the innovative service clues that influence customers' perception specifically in this hotel concept.

The boutique hotel sector has emerged as a new trend in Southeast Asia where customer satisfaction is always a concern of practitioners. Reports indicate that boutique hotel operations are emerging as a very promising market that contributes to the development of the hospitality industry in China (Lye 2017). Meanwhile, the boutique hotel market seems to be maturing, and determining factors that impact customer satisfaction are a concern of hoteliers in Singapore (Noble 2018). In Vietnam, the boutique hotel sector is currently in an early stage of following the trend to satisfy customer expectations for a unique experience. The development of the boutique hotel sector is promising for the development of tourism and hospitality in Vietnam (Andrews 2018). Thus, exploring customer perception and attitude toward the innovativeness of the boutique hotel operations can help hoteliers to optimise their marketing strategies as well as improving operational efficiency.

RQ1. What are the innovative service clues that influence customer satisfaction?

RQ2. How do innovative service clues influence customer satisfaction?

\section{LITERATURE REVIEW}

This section reviews the perspectives of Service Innovation and hospitality filed to emphasise the importance of innovative service clues on customer satisfaction. Studies of Service Innovation have indicated that operational performance and customer evaluation are important mutually to one another. In other words, to create a successful innovation it is not only the matter of organising and operating but also the contribution of customers via feedback. Besides, there is a call in the hospitality industry for service innovation that focuses on delighting customers with a new and unique experience, which are different from the commercial standardisation.

\subsection{Service Innovation}

The classification of service innovation in the existing literature is controversial. Traditionally, researchers have been following the perspective of assimilation on studying service innovation (Gallouj 2002; Carlborg et al. 2014; Witell et al. 2016). From this perspective, these researchers assert that theories and instruments, which are traditionally used for product innovation, can be adapted for analysing service innovation (Kindström and Kowalkowski 2014). This school of thought defines individual firms as service producers and customers as service consumers, which are not associated with producing the service (Carlborg et al. 2014). Furthermore, there is the assumption that services are supplier-dominated, in which service firms are passive recipients of innovations from other sectors (Witell et al. 2016). This perspective is also called as Supplier-Dominated Logic which emphasises on the importance of technology and capital in influencing the development of the service sector (Gallouj and Savona 2009; Khan and Khan 2009; Toivonen and Tuominen 2009; Lee et al. 2014). However, the theories and instruments of product innovation have been adapted in this perspective without translation or modification (Snyder et al. 2016; Witell et al. 2016). This comes to an argument of the demarcation perspective whereby the assimilation perspective has dismissed the specificities of service's characteristics. They also claim that the school overvalued the contribution that services can make to products innovation (Gadrey et al. 1995; Gustafsson et al. 2012; Snyder et al. 2016; Witell et al. 2016).

The demarcation perspective argues for the differences in product innovation and service innovation. It also emphasises the development of new theories and models about service innovation that the service innovation is treated in a different domain, which is called Service-Dominant Logic (Fitzsimmons and Fitzsimmons 2000; Droege et al. 2009; Baron et al. 2010; Ordanini and Parasuraman 2010; Lusch and Nambisan 2015; Skålén et al. 2015). This school of thought considers the important elements of service delivery that has been neglected by Supplier-Dominant Logic. Specifically, customers not purchase for product only, they also expect value, performance and experience created in such exchange process (Hipp and Grupp 2005; Berry et al. 2006; Lusch and Nambisan 2015). As such, the ServiceDominant Logic concerns to the aspects of intangible nature of services and the need for customer integration (Vargo and Lusch 2007; Gustafsson et al. 2012; Witell et al. 2016). Besides, Service-Dominant Logic believes that service innovation can be created beyond the contributions of organisational knowledge and non-technological elements (Hertog et al. 2010; Hertog et al. 2011). This perspective has been recognised to contribute to the expansion of service innovation (Witell et al. 2016).

Another service innovation school of thought should also be considered is the synthesis perspective, which emphasises the importance of combining both the assimilation and the demarcation perspective (Witell et al. 2016). Researchers in this school of thought highlight the importance of the integrated definition of service innovation that is not limited to the technological innovations; they also argue that the definition of service innovation must be broad enough to encompass manufacturing and pure-service operations (Snyder et al. 2016). This synthesis perspective proposes that the combination of both perspectives may influence significantly and feasibly to economic growth (Gallouj 2002; Witell et al. 2016).

\subsection{Innovative Service Clues}

From the perspective of service operation, customer satisfaction is not only influenced by product and physical 
values but also by the intangible values of service delivery (Parasuraman et al. 1990). The reaction of customers as evaluating and giving opinions about the service quality of every individual event is defined as Transaction-Specific Satisfaction (Bitner and Hubbert 1994; Jones and Suh 2000). Before evaluating the services, customers have their expectation toward the service performance which is the antecedent of satisfaction (Zeithaml et al. 1990). The expectation, which is formed by accumulated experience, knowledge, information and demand, influences customer actual perception. The actual perception of service performance involves comparing the expected values and the actual values that they receive (Oliver 1977; Zeithaml et al. 1990). Thus, the satisfaction level can be higher or lower depending on expectation. Understanding how customers perceive and evaluate the services are critical points for promoting favourable behavioural intentions such as returning and recommending (Chua et al. 2014; Haddad et al. 2015; Ali et al. 2016; Ahmad et al. 2017).

Berry et al. (2006) classified the service attributes into three groups which are Mechanic Clues, Humanic Clues and Functional Clues. First, Mechanic Clues consist of the sensory presentation of the service; for instance, ambience, scent, light, touch, taste and sound (Berry et al. 2006; Chua et al. 2014; Truong et al. 2017). Second, Humanic Clues consist of the appearance and behaviour of service staff, who directly interact with and deliver the service values to customers (Berry et al. 2006). Service staff is considered as one of the key players that influence customer impression of the service performance. Humanic Clues are determinants that have always been a concern to scholars in the hospitality field to maximise the positive experience for customers (Chua et al. 2014; Nguyen et al. 2014; Garg and Amelia 2016; Truong et al. 2017). Third, Functional Clues are those that deliver the efficiency and accuracy of the technical quality at its presence or absence (Berry et al. 2006).

The innovative service clues should be new regarding customer accumulated experience, knowledge and information. To influence customer satisfaction of innovative services, the service operations can create innovative clues by service delivery (Lusch and Nambisan 2015). The distinctive feeling may happen at the time the customers encounter with the sensory attributes of the service operation, and they were entirely unaware of the feeling they may receive (Bramble 2013). Thus, the Innovative Mechanic Clues can be perceived through the five senses attached with positive emotions to give customers unexpected joy. The tactic of service script that guides the staff's behaviour toward customer-oriented interaction can promote customer perception of warmth and friendliness (Nguyen et al. 2014). The warmth, caring and friendliness are important attributes that offer customers the distinctive memories in the century of standardised service with the development of machine and technology (Kattara and ElSaid 2014; Gabriel et al. 2016). Therefore, Innovative Humanic Clues can be reflected by the staff's manner, appearance and communication technique that encourages customer citizenship and the mutual bonding between service staff and the customers. Positive customer experience expects the innovation delivered by technology and digital applications to be convenient and safe (Kattara and El-Said 2014; Moon et al. 2015; Zhang and Hou 2017). Therefore, Innovative Functional Clues include technological products, digital applications and programs embedded with efficiency to facilitate the convenience and safety for customers. Innovative Functional Clues could optimise service performance technically toward customer satisfaction of innovativeness.

\subsection{The Nature of Hospitality Service Operations}

The most dominated approach for defining hospitality is suggested from the work of Brotherton and Wood (2000). The authors define the concept of hospitality that "A contemporaneous human exchange, which is voluntarily entered into, and designed to enhance the mutual well-being of the parties concerned through the provision of accommodation, and/or food, and/or drink" (Brotherton and Wood 2000, p. 142). Although the definition has been challenged as not to capture the sense of the exciting, vibrant and creative of the industry in the practice, it essentially highlights the importance of hospitableness centred by food, drink and accommodation (Telfer 2000; Hemmington 2007). Additionally, Slattery (2002) emphasises the three domains approach to define hospitality which are: social/cultural, private and commercial; the author also advises on the context of hospitability business that is industry, corporate and the venue context (Lynch et al. 2011). This classification of hospitality operations has been evaluated as very useful and worth considering of scholars for hospitality studies (Hemmington 2007; Ottenbacher et al. 2009; Ariffin and Maghzi 2012). In such situation, there is a call for investigators to looking at hospitality as a multi-aspect definition to understand and create specific research contexts that can help to explain the characteristics of hospitality comprehensively (Hemmington 2007; Ottenbacher et al. 2009; Lynch et al. 2011; Lashley 2015).

Hospitality is not just about commercial service activities but the warranty of enjoyment, feeling and experience. First, hospitality in the domain of cultural considers the social setting, which is expected to give the customers the cultural value, the expected meaning of religion that the host should be able to offer (Lynch et al. 2011; Ariffin and Maghzi 2012). These cultural values should be well delivered to the customers through food, drink, entertaining activities and accommodation setting (Lashley 2015). In this domain, the most important element is not about the impression of interesting physical materials, but rather the experience, the feeling and the spirit of culture should be well served to the customers (Slattery 2002). Second, the domain of private concerns to the feeling of home that the customers could receive, and the service must be charged reasonably. In other words, the customers expect the value of the service delivered through food, drink, accommodation and leisure activities in the highest standard of hospitableness, which exceeds the price (Slattery 2002). Besides, in the private domain, the relationship between service providers and service receivers is emphasised as a critical point in business management (Slattery 2002; Ottenbacher and Gnoth 2005; Lashley 2015). Whereas, the domain of commercial is more concentrating on the profitability and the wealthiness of the service operations rather than putting customers' pleasure as a priority (Slattery 2002; Lashley 2015). The customers will receive the service called "hospitality" as long as they pay for their demand; 
thus, types of hospitality operations are various such as lodge, bars, clubs, tourism operations, etc. However, the customers, in this domain, do not receive the hospitableness as the academics have defined (Slattery 2002; Lashley 2015). Lashley (2015) emphasised that almost of studies have been done in the hospitality appears to focus on the commercial domain, with the employment of high-technology to ensure the satisfaction and loyalty of customers for profit concentration (Ottenbacher et al. 2006; Ottenbacher 2007), but neglect to study the influence of private and social domain on actual experience of customers. Generally, according to the definition of hospitality, the service of pure hospitality operations should ensure the hospitable and memorable experience with entertainment, specialised service quality through service delivery; service products and facilities with high-tech functions to fulfil the customers' expectation (Slattery 2002; Lashley 2008; Ottenbacher et al. 2009; Rogerson 2010; Lynch et al. 2011; Lashley 2015).

Regarding the highly competitive market, hoteliers and scholars have investigated the implications of the service innovation to be distinct from competitors. The innovation should be consistent with customer need and preference to be accepted (Rogers 2010). Tourists are potential customers for hotels located in historical or tourist places that satisfying their expectation for a new experience with innovative values of the hotel operations can encourage their revisiting (Assaker et al. 2011; Ariffin and Maghzi 2012). It is critical to creating a memorable experience by optimising the innovation in interior design, food and beverage and the total ambience to customers (Gilmore and Pine II 2002; Ottenbacher and Gnoth 2005). It appears that scholars and practitioners have increasingly considered the importance of innovative service attributes to satisfy customer expectation for a new experience (Torres and Kline 2013; Ordanini et al. 2014; Tsai et al. 2015; Shahi and Goswami 2018).

\section{RESEARCH METHOD}

The qualitative method was employed in this study aiming to have an in-depth understanding of customer perception and evaluation toward innovative services. The objectives are to define the main themes and subthemes of Innovative Service Clues and Innovativeness that influence customer satisfaction and behavioural intentions. To address the research questions, the deductive content analysis with thematic approach was employed to code and analyse the data. The deductive content analysis is practised when the researchers already identified the expected themes based on the knowledge about the phenomenon taken from the literature (Fereday and Muir-Cochrance 2006; Elo and Kyngas 2007; Elo et al. 2014; Javadi and Zarea 2016; Bernard et al. 2017). Thematic analysis approach helps to organise and describe an in-rich data set. Specifically, the approach identifies, analyses and reports patterns within data (Braun and Clarke 2006). Thus, the deduced themes can be considered as valid and reliable if the content of the themes adequately represents the identified concepts, and capture what was intended (Vaismoradi et al. 2013; Elo et al. 2014).

The development of social media provides online public places for firms to gather and interpret user-generated opinions, converting unstructured text into useful, meaningful, nontrivial information (Netzer et al. 2012; Vo Thanh and Kirova 2018). Thanks to the development of user- generated travel websites, customers have more opportunity to seek information from non-virtual communities and to share their opinions about service quality of hospitaly and tourism operations with others (Dinçer and Alrawadieh 2017). Customers believe that information shared by peers are more reliable thus more influential than those provided by marketers (Assaker, Vinzi and O'Connor 2011). Information provided by end-users on the social media is an open source that helps managers to monitor customer satisfaction more efficiently (Cetin and Dincer 2013; Dinçer and Alrawadieh 2017; Xiang et al. 2017; Pee, Jiang and Klein 2019). For example, Dinçer and Alrawadieh (2017) used content analysis approach to analyse customers' comments on the service quality of hotels in order to determine factors that influence customer satisfaction. Therefore, this research will collect and analyse the content of reviews of international customers, who have experienced the innovative hotel services, on popular hospitality and tourism webpage - TripAdvisor (EuromonitorInternational 2018).

There are three main phases for analysing deductive content: collecting suitable data, getting familiar with the content and categorising the content (Vaismoradi et al. 2013; Elo et al. 2014; Murray et al. 2016; Whalen 2018). Firstly, the research population is boutique hotels. Boutique hotels are known as the concept that emphasises the distinctive experience by focusing on innovative ambience and services, the feeling is perceived differently from the standardised commercial hotel (McIntosh and Siggs 2005; Van Hartesvelt 2006; Winnick 2011; Jones et al. 2013). The hotel concept focuses on distinctive design of room size, interior and exterior; high level of personalised attention that targets on psychographic niche markets; located in urban, city centres or in locations that demonstrate the cultural or historic value of a region (McIntosh and Siggs 2005; McNeill 2008; Mun Lim and Endean 2009; Rogerson 2010; Henderson 2011; Jones et al. 2013). Secondly, the research strategy was to use the search engine of the webpage to look for qualified reviews. The researchers searched, collected and analysed one thousand reviews of international tourists who gave opinions on the innovative services of boutique hotel operations throughout Vietnam on TripAdvisor webpage. There were 20 boutique hotels from different tourist cities selected, namely Hanoi, Hoian, Danang, Ho Chi Minh and Quang Ninh. Thirdly, this study employed the QSR Nvivo 12 program to store and code the data files. Nvivo program has been shown as an efficient tool for qualitative study which boosts the accuracy of data analysis (Zamawe 2015). Each file contains four to five reviews which have more than 50 words. Each review was read and coded into their main themes. The sub-themes and emerging themes were explored subsequently to define what are the Innovative Service Clues and Innovativeness attributes, and how those attributes influence customer satisfaction from the perspective of international tourists visited Vietnam.

\section{CONTENT ANALYSIS OF TRIPADVISOR REVIEWS}

Having conducted content analysis of one thousand reviews which were grouped into 200 files, a count of the codebook was generated. The most frequently mentioned attributes included the following: Innovative Humanic Clues 
(461 references), Innovative Mechanic Clues (331 references), Innovative Functional Clues (239 references). Specifically, the Innovative Humanic Clues consist of Service Delivery (177 references), Communication (92 references), Personalised Service (48 references), Appearance (38 references), Problems Solving (32 references). The Innovative Mechanic Clues consist of Taste (159 references), Sight (113 references), Touch (38 references), Sound (34 references), Smell (34 references). The Innovative Functional Clues consist of Rooms (141 references), Facilities (108 references) and Technology (14 references). Table 1 summaries the relationships amongst the main themes and sub-themes with detailed description.

\subsection{Innovative Humanic Clues of Boutique Hotel Operations}

The innovative clues of service staff's behaviour and appearance can influence customer transaction-specific satisfaction. Customers evaluated the technique of how the staff solve problems and delivering service. Besides, customers were highly delighted during and after their visit thanks to the personalised services that created memorable experiences. Innovative clues of communication technique between staff and customers also influence customer satisfaction. The appearance of the staff is another clue that customers perceived as different from other hotel operations.

\subsubsection{Service Delivery}

The technique of delivering service in boutique hotels was perceived as different from other hotel operations. Customers received the kindness and services beyond duty from staff which brought them the family feeling. More than prompt service, the staff subtly noticed customers need and offered sincere help that customers had not expected. The exceptional service was assessed on staff manners such as attentiveness, warmness, friendliness and courtesy care.

\subsubsection{Communication}

Customers perceived the warm interaction when they were approached and called by their first name during the stay. They found it helpful and the communication between staff and customers was closer thanks to the detailed advice and recommendation on places to visit. The language and tone of voice when communicating with customers are also important. Specifically, customers preferred to talk and were willing to give feedback about the hotel operations when they perceived the quality of communication technique from the service staff. Furthermore, the customers said that the way the service staff taking care of them made their stay more memorable. For example:

Cozy Hoian Boutique Villas, reviewer 1: "Staff is [sic] excellent, helpful and professional. They impressed us because they remember guests' names and greet you by name each time they see you. The host was sensational with perfect English and was very helpful with all our requests and even more information than we needed."

Thus, it can be said that being innovative in communication is focusing on techniques that make customers feel comfortable and respectful. Concerning language with an appropriate tone of voice can be a technique that makes customers feel warm and encouraged to share their opinion about the service quality. Also, the customers' feedback should be listened carefully so that they feel that their contribution is worthy. The service staff should understand customers' emotions and communicate appropriately to both satisfying customers and receiving their contribution in order to improve or renovate the services.

\subsubsection{Personalised Service}

Customer actual perception is higher than expected when their unique requests were quickly and accurately responded. Moreover, noticing customer need and offering special assistance before being requested was found as another clue that influences customer satisfaction. The customers felt thankful as being treated like family members. The positive feeling was created at the moment they felt they were well looked after. Customers said that they could hardly find these values in other normal hotel operations. For example:

Hanoi La Siesta Hotel, reviewer 1: "The hotel staff went the extra mile in providing personalized service by checking the remaining value [sic] in my Vinaphone SIM card, which helped me avoid un-necessary expenditure to top up the amount of data in my SIM card on my last day in Hanoi. That was truly an exceptional service."

The above reviews demonstrate that another innovative humanic clue is the technique the service staff deliver personalized service. Personalized services are the services that showing how customer's specific needs are responded. To impress customers with innovation in service delivery, the service staff are expected to go beyond their duty to taking care of their customers so that the customers can feel the warmth as they are treated as family members; thus, having positive memories about the hotel.

\subsubsection{Appearance}

Service staff's appearance with smile, uniform and manner is another clue that influences customer perception of difference. Customers notice service staff's manner and assess the friendliness which determines the unique and outstanding of the service environment from other types of hotel operation. Greeting with a natural smile can comfort customers the experience that makes them feel like home and being welcomed. Customers also consider the service quality that reflected through the staff's manner of care and assesses the working attitude of staff through smiles. The uniform is another attribute that delivers the unique culture of the hotel operation as well as the cultural value of the location the hotel operates.

Therefore, the appearance of service staff can also an attribute toward innovative service clues that influence customer satisfaction. Customers do not only assess the accommodation and the services but also concern the quality of service staff's manner and their uniform. These clues should be considered so that customers can have a positive impression of the innovativeness of the boutique hotels.

\subsubsection{Problem Solving}

The quality that the service staff can go over and beyond the duty to solve problems carefully was perceived as touching customers' feeling positively. Focusing on detail issues, the service staff gave customers a higher level of satisfaction. Besides, service staff had impressed customers with their professionalism such as truly understanding 
customers circumstance and responding quickly in any situations. The service staff was said flexible and considerate solving problems. For example:

Cozy Hoian Boutique Villas, reviewer 8: "The first morning I was there, I had terrible sinus pressure and asked Kathy if there were any local remedies. She quickly whipped me up some fresh ginger tea and sent someone to the pharmacy to get me some nasal spray. This all happened very quickly and I was feeling great."

The ability that service staff go beyond their duty to solve problems creatively and flexibly can also impress customers. As demonstrated above, customers experienced the warmth and caring from service staff. Hoteliers should also consider this attribute for innovative humanic clues to delight customers.

\subsection{Innovative Mechanic Clues of Boutique Hotel Operations}

The innovative clues of the total ambience perceived through the five senses of customers influence customer transaction-specific satisfaction. Customers appear to talk about the unique feeling they received before, during and after every event they interacted with the boutique hotel services. Specifically, the special point of food and beverage services of the hotel offered customers the favourable taste perception. Besides, customers assessed the creative clues of the outside and inside view of the hotel that influences their sight perception. The different feelings of touching also delighted customers. The technique to deliver soft sound effect within the hotel operations and the nearby natural sound favourably influenced customer perception. Besides, focusing in detail with aroma stimulated customers' smell perception, the distinctive and pleasing aroma was said to give customers comfortability.

\subsubsection{Taste Perception}

The first perceived transaction is delivered by tasting, which refers to the meals of the restaurant service in the boutique hotels. The meals should be able to deliver the culture values by their authentic taste. The variety and freshness of food with its presentation are clues can be creatively offered to the customers. Besides the key role of breakfast, additional food and beverage services such as dinner, lounge or bar also influence customer satisfaction. For example:

MJ Marvel Hotel, reviewer 2: "We were also thoroughly impressed with the daily breakfast which had a great variety of western/eastern foods both served buffet style and a small menu made to order. Everything was delicious and probably the best free hotel breakfast I've had!"

\subsubsection{Sight Perception}

The second perceived transaction is delivered by sight, which is the innovative exterior of the hotel operations. The artistic ad opened the design of the hotel that fits with natural and cultural values at its location is important to delight customers. The outside view from the hotels is critical to satisfying customer expectation for the sightseeing experience. Customers were found enjoy exploring the culture by visiting nearby attractions or having chances to interact with other local citizens. Hotel's location and distance to attractions were mentioned frequently. For example:

Legacy Yen Tu, reviewer 1: "The hotel and the setting are beautiful. The design and decor are by the [sic] famous Bill Bensley, and his astonishing using Vietnamese vernacular style"

Legacy Yen Tu, reviewer 2: "The most striking thing about this resort is its design and architecture! It's a well done [sic] job by American architect Bill Bensley who tastefully applied the famous Tran dynasty palace model into the design of this resort! The reception lobby, the restaurant and the bar were exceptionally beautiful. An eclectic mix of traditional Vietnamese and local flavours that made people feel both relaxing and impressed at the same time!'

The innovative clues delivered by the inside view of the hotel operations is another aspect that hoteliers should concern. The harmony of creative interior design, which consists language of architecture, material, colour and lights, plays an important role to give customer relaxing moments, telling stories of culture they are visiting. For example:

La Residencia, reviewer 2: "Recently spent 10 days at the La Residencia Hotel and Spa, which offers a rustic blend of the old French style, overlaid with Vietnam's cultural atmosphere."

\subsubsection{Touch Perception}

The third perceived transaction is delivered by touching, which is the special concern to bed, pillow and sofa organised in within the boutique hotel operation. The unique point of boutique hotel design is small in room size. Thus, a reasonable organisation of materials and facilities with comfortable touch is one of the determinant factors to satisfy customers. Besides, additional services such as spa and special treatment offered by the boutique hotel operation are activities can delight customers.

\subsubsection{Sound Perception}

The fourth perceived transaction is delivered by the sound effect which refers to music inside the hotel or natural sound nearby. The harmony of music in the hallway of the restaurant is the clue that can influence customer satisfaction. Besides, customers perceive the natural and local sounds from countryside, vehicles or animals as they can exploring the culture which satisfies their expectation when visiting the new country. However, the sound should be carefully concerned to avoid bothering customers by the noise at night, ensuring the sleep quality for customers.

\subsubsection{Smell Perception}

The fifth perceived transaction is delivered by the aroma effect which refers to the pleasant smell in the lobby, rooms, elevators or spa service. The innovative clue to influence customer satisfaction is the unique aroma impressing customer perception at the first moment they encounter with the services. Also, the differences in smells for different bedroom were perceived by customers with a joyful and interesting experience. Customers found it relax and calm atmosphere delivered by the aroma. 


\subsection{Innovative Functional Clues of Boutique Hotel Operations}

The innovative clues of facilities, rooms and technological equipment influence customer transactionspecific satisfaction. Focusing on detail with creative design and high quality of rooms' amenities to facilitate the convenience as well as enjoyment. For instance, the bed was well concerned with comfortability and decoration to ensure the quality of sleep. The unique design of rooms with small about size but with balcony to emphasise the feeling of home as well as relaxation. As a hotel concept that emphasises on experience and feeling, technological equipment seems to be less concerned but free and high wi-fi speed.

\subsubsection{Facilities}

Innovative clues of facilities that mentioned are related to areas and transport for social communication with other customers, staff and locals that delight their experience. The pool with mini bar for social interaction seems to be a must to satisfy customer expectation in boutique hotel operations. Free shuttle bus and bikes that help travelling to local areas are amenities that the foreign mentioned as a convenience. Some boutique hotels even offer private beach area for their customers with additional food and beverage services which were assessed as valuable experience by the customers. The quality of beds and curtains are other clues can be innovative to deliver the outstanding of its function ensuring the satisfaction of sleep with detailed decoration and comfortability. Besides, the room amenities can be innovative clues that influence customer perception of innovativeness.

\subsubsection{Rooms and Technology}

The remarkable feature of the boutique hotel is the design of rooms which is perceived as innovative. Rooms were perceived not only a place for sleeping but relaxing. Customers enjoy rooms with balcony for sightseeing as well as felling more spacious and opening. The room size and decoration were also important to ensure customer perception of comfortability as well as a new experience. Some hotels' room was perceived as small, but they still feel comfortable due to the unique decoration and reasonable amenities arrangement. Besides, the technological aspect of boutique hotels that customers concern is the convenience of wi-fi connection. Customers were delighted with free and fast speed of the wi-fi connecting with other amenities which had been unexpected.

Table 1 Themes and sub-themes of innovative service clues

\begin{tabular}{|c|c|c|c|}
\hline Themes & \multicolumn{2}{|l|}{ Sub-themes } & \multirow{2}{*}{$\begin{array}{c}\begin{array}{c}\text { Number of } \\
\text { References }\end{array} \\
461\end{array}$} \\
\hline $\begin{array}{l}\text { Innovative Humanic } \\
\text { Clues }\end{array}$ & \multicolumn{2}{|c|}{$\begin{array}{l}\text { Staff's manner, appearance and communication technique that } \\
\text { encourages customer citizenship and the mutual bonding between } \\
\text { service staff and the customers }\end{array}$} & \\
\hline & Service Delivery & $\begin{array}{l}\text { The warm and attentive technique of delivering } \\
\text { service }\end{array}$ & 177 \\
\hline & Communication & $\begin{array}{l}\text { Friendly and efficient communication between } \\
\text { service staff and customers }\end{array}$ & 92 \\
\hline & $\begin{array}{l}\text { Personalised } \\
\text { Service }\end{array}$ & Focus-on-detail caring & 48 \\
\hline & Appearance & Cultural uniform with warm greeting & 38 \\
\hline & Problems Solving & Go over and beyond duty to solve problems & 32 \\
\hline \multirow[t]{6}{*}{$\begin{array}{l}\text { Innovative Mechanic } \\
\text { Clues }\end{array}$} & \multicolumn{2}{|c|}{$\begin{array}{l}\text { Five senses attached with positive emotions to give customers } \\
\text { unexpected joy }\end{array}$} & 331 \\
\hline & Taste & The quality of food and beverage services & 159 \\
\hline & Sight & The inside and outside view of service operation & 113 \\
\hline & Touch & The comfort quality of facilities & 38 \\
\hline & Sound & $\begin{array}{l}\text { Inside and outside sound quality of service } \\
\text { operation }\end{array}$ & 34 \\
\hline & Smell & $\begin{array}{l}\text { The inside and outside aroma of service } \\
\text { operation }\end{array}$ & 34 \\
\hline \multirow[t]{4}{*}{$\begin{array}{l}\text { Innovative } \quad \text { Functional } \\
\text { Clues }\end{array}$} & \multicolumn{2}{|c|}{$\begin{array}{l}\text { Technological products, digital applications and programs embedded } \\
\text { with efficiency to facilitate the convenience and safety for customers }\end{array}$} & 239 \\
\hline & Rooms & Distinctive room size and the arrangement & 141 \\
\hline & Facilities & $\begin{array}{l}\text { Facilities to promote social interaction amongst } \\
\text { staff and customers, nature encountering }\end{array}$ & 108 \\
\hline & Technology & Digital applications to promote the convenience & 14 \\
\hline
\end{tabular}




\section{PROPOSITIONS DEVELOPMENT}

This section discusses and develops a set of propositions based on the findings of the website content analysis and relevant works of literature. Specifically, the findings have suggested that customers perceived the innovativeness of boutique hotel operations as TransactionSpecific Satisfaction. Determinants of Transaction-Specific Satisfaction were found as Innovative Humanic Clues,
Innovative Mechanic Clues and Innovative Functional Clues. The findings of the website content analysis also suggested the attributes associated with their respective determinants.

Table 2 demonstrates the attributes described by existing studies. By relating findings from the analysis and the discussion of studies, the conceptual model is going to be proposed in the following section.

Table 2 Determinants of innovative humanic clues perceived as transaction-specific satisfaction based on relevant literatures

\begin{tabular}{|c|c|c|c|}
\hline Determinants & Attributes & Descriptions & References \\
\hline \multirow[t]{5}{*}{ Innovative Humanic Clues } & Service Delivery & $\begin{array}{l}\text { The warm and attentive } \\
\text { technique of delivering service }\end{array}$ & $\begin{array}{l}\text { Lusch and Nambisan (2015); } \\
\text { Skålén et al. (2015); Wang et } \\
\text { al. (2017) }\end{array}$ \\
\hline & Communication & $\begin{array}{l}\text { Friendly and efficient } \\
\text { communication between service } \\
\text { staff and customers }\end{array}$ & $\begin{array}{l}\text { Chen et al. (2011); Chen } \\
\text { (2011); Chen et al. (2017); } \\
\text { Ali et al. (2018) }\end{array}$ \\
\hline & Personalised Service & Focus-on-detail caring & Wang and Beise-Zee (2013) \\
\hline & Appearance & $\begin{array}{l}\text { Cultural uniform with warm } \\
\text { greeting }\end{array}$ & $\begin{array}{l}\text { Walls (2013); (Bagdare } \\
\text { 2015) }\end{array}$ \\
\hline & Problems Solving & $\begin{array}{l}\text { Go over and beyond duty to solve } \\
\text { problems }\end{array}$ & Torres et al. (2014) \\
\hline \multirow[t]{5}{*}{ Innovative Mechanic Clues } & Taste & $\begin{array}{l}\text { The quality of food and beverage } \\
\text { services }\end{array}$ & $\begin{array}{l}\text { Garg and Amelia (2016); Kim } \\
\text { et al. (2018) }\end{array}$ \\
\hline & Sight & $\begin{array}{l}\text { The inside and outside view of } \\
\text { service operation }\end{array}$ & $\begin{array}{l}\text { Tsai et al. (2015); Shahi and } \\
\text { Goswami (2018); Wang et al. } \\
\text { (2018) }\end{array}$ \\
\hline & Touch & The comfort quality of facilities & $\begin{array}{l}\text { Tsai et al. (2015); Shahi and } \\
\text { Goswami (2018); Wang et al. } \\
\text { (2018) }\end{array}$ \\
\hline & Sound & $\begin{array}{l}\text { Inside and outside sound quality } \\
\text { of service operation }\end{array}$ & $\begin{array}{l}\text { Tsai et al. (2015); Shahi and } \\
\text { Goswami (2018); Wang et al. } \\
\text { (2018) }\end{array}$ \\
\hline & Smell & $\begin{array}{l}\text { The inside and outside aroma of } \\
\text { service operation }\end{array}$ & $\begin{array}{l}\text { Tsai et al. (2015); Shahi and } \\
\text { Goswami (2018); Wang et al. } \\
\text { (2018) }\end{array}$ \\
\hline \multirow[t]{3}{*}{ Innovative Functional Clues } & Rooms & $\begin{array}{l}\text { Distinctive room size and the } \\
\text { arrangement }\end{array}$ & Shahi and Goswami (2018) \\
\hline & Facilities & $\begin{array}{l}\text { Facilities to promote social } \\
\text { interaction amongst staff and } \\
\text { customers, nature encountering }\end{array}$ & $\begin{array}{l}\text { Cetin and Walls (2016); Xu } \\
\text { and Li (2016); Shahi and } \\
\text { Goswami (2018) }\end{array}$ \\
\hline & Technology & $\begin{array}{l}\text { Digital applications to promote } \\
\text { the convenience }\end{array}$ & $\begin{array}{l}\text { Kattara and El-Said (2014); } \\
\text { Barrett et al. (2015) }\end{array}$ \\
\hline
\end{tabular}

\subsection{Innovative Humanic Clues}

The Innovative Humanic Clues in hotel operations refer to the service staff's attributes that directly influence customer impression and perception of new experience. Customer roles and behaviour in service delivery are considered as key determinants to result in a high-quality service outcome (Vargo and Lusch 2007). In a customeroriented service operation, the mutual interaction between service staff and customers is important to encourage customer feedback and contribution to innovative service performance (Lusch and Nambisan 2015; Skålén et al. 2015; Wang et al. 2017). Service operations, thus, practise the service script that guides service staff the techniques to serve and encourage customer engagement for feedback, creating emotional bonding mutually (Chen et al. 2017; Ali et al. 2018). Hospitality operations should concern team engagement in an innovation climate which enables service staff to be flexible, and to have innovative behaviours that satisfy customers' need while ensuring the consistent service delivery (Skålén et al. 2015; García-Buades et al. 2016; Wang et al. 2017). Wang and Beise-Zee (2013) suggested that focusing on detail caring can stimulate customer perception of warmth of the services which make it distinctive from the standardised hotel services. Professional greeting with warmness ensured as well as cultural uniform can delight customer experience (Walls 2013; Bagdare 2015). Service staff with the ability to go beyond their duty to solve problems was also suggested as a technique to influence customer satisfaction (Torres and Kline 2013; Torres et al. 2014).

Proposition 1: Innovative Humanic Clues influence customer transaction-specific satisfaction of hotel service performance. 


\subsection{Innovative Mechanic Clues}

The Innovative Mechanic Clues in hotel operations refer to the ambience values that deliver a surprising experience to customers. Compared to business travellers, the leisure travellers prefer to experience the values of ambience that reflected through entertainment lounges, the nearby sightseeing and the attractiveness of interior design (Tsai et al. 2015). Hoteliers are suggested to concern the local culture art into the design to create the innovation that impresses customer perception of ambience (Shahi and Goswami 2018). The innovative ambience is supposed to deliver unforgettable memories, a unique experience of comfort that influence customer satisfaction not only physically but also psychologically (Shahi and Goswami 2018). Together with the interior design, the natural light, impressive softness of furniture, the memorable scents should be concerned to satisfy customers' expectation for innovation in the hotel (Tsai et al. 2015; Shahi and Goswami 2018; Wang et al. 2018). The artistic servicescape with serene music, pleasing sounds of bird or insects, naturalbased elements, fresh air with the scent of flowers were found to stimulate customer's sensory experiences (Cheng et al. 2016; Horng et al. 2017; Lee and Cheng 2018). Using artistic values to deliver a new experience to customers has been considered as a new strategy in hospitality operations (Shahi and Goswami 2018; Wang et al. 2018). The value of delivering food and beverage services was also suggested as a technique can delight customer experience for innovativeness (Garg and Amelia 2016; Kim et al. 2018).
Proposition 2: Innovative Mechanic Clues influence customer transaction-specific satisfaction of hotel service performance.

\subsection{Innovative Functional Clues}

The Innovative Functional Clues in hotel operations refer to the employment of new technological products and programs, or new services and techniques to facilitate the convenience and safety for customers, enhancing the innovative experience. Information and technology communication program have been shown to influence customer satisfaction by improving the service of rooms, food and beverage as well as back and front office (Kattara and El-Said 2014; Chevers and Spencer 2017). The in-room facilities and other amenities such as wi-fi connection, aircondition, pool and spa service should always need to consider for renovation (Barrett et al. 2015; Xu and Li 2016). Creative idea for room size aligned with bath-room decoration and other innovative functionalities within the hotel operations were found to influence customer satisfaction, emphasising unique and memorable experience (Barrett et al. 2015; Cetin and Walls 2016).

Proposition 3: Innovative Functional Clues influence customer transaction-specific satisfaction of hotel service performance.

\section{CONCEPTUAL MODEL}

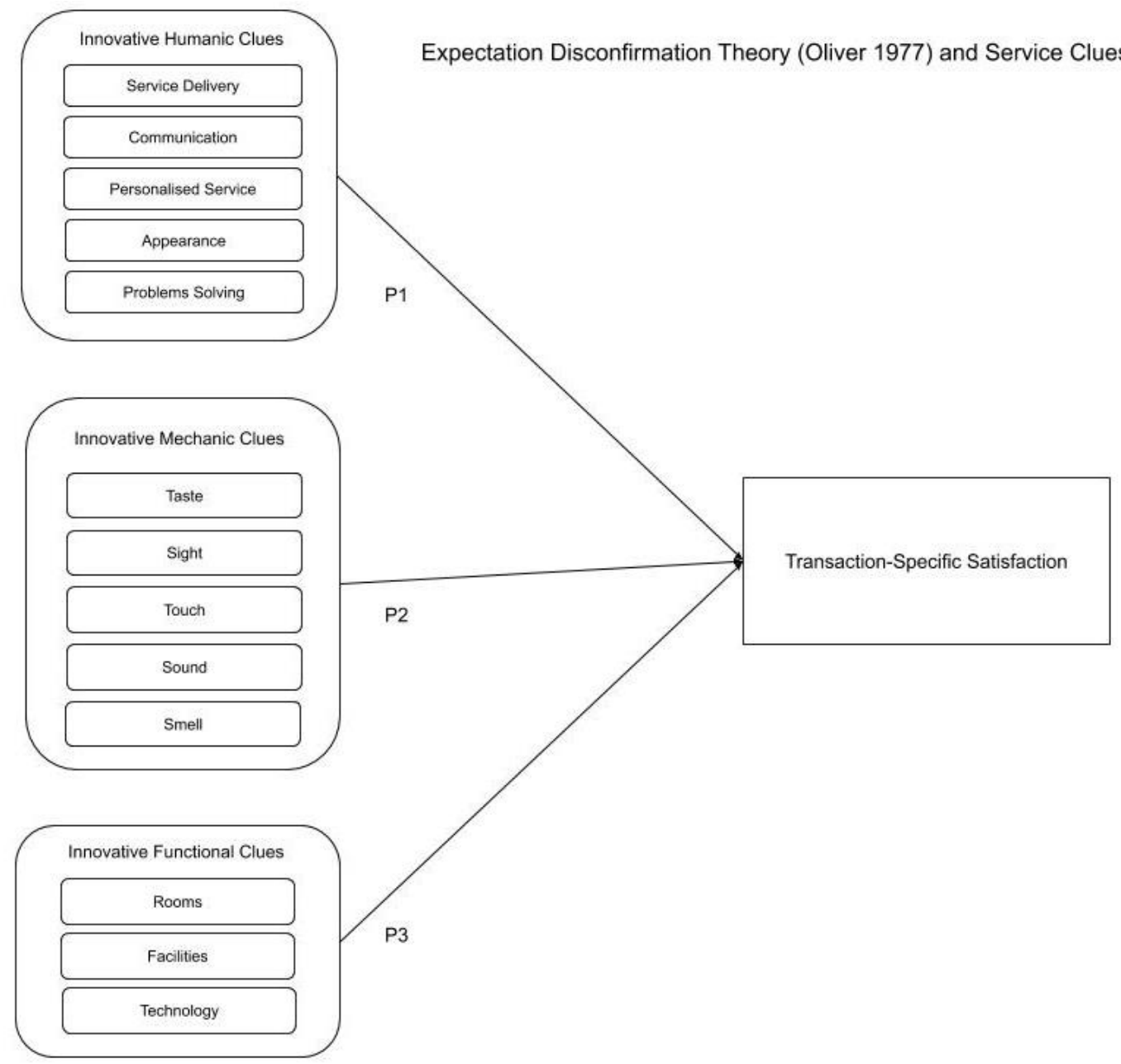

Figure 1 The impact of innovativeness of hospitality service operations on customer satisfaction 
This study proposes a conceptual model that demonstrates the relationship between innovativeness and customer satisfaction in the context of boutique hotel operations. The deductive thematic analysis was employed in this study to define the main themes and sub-themes of innovativeness that influences customer satisfaction. The conceptual model also developed based on key theories and relevant literature such as Expectation Disconfirmation Theory (Oliver 1977) and Service Clues (Berry et al. 2006).

Regarding Transaction-Specific Satisfaction, customers perceive the innovativeness in term of Innovative Humanic Clues, Innovative Mechanic Clues and Innovative Functional Clues. The Innovative Humanic Clues consist of service delivery, communication, personalised service, appearance and problems solving. The Mechanic Clues consist of five senses perception which is taste, sight, touch, sound and smell. The Innovative Functional Clues consist of rooms, facilities and technology.

\section{CONCLUSION AND IMPLICATIONS}

Service innovation studies by scholars and practitioners have been concerned with the promotion of customer satisfaction to a higher level. Digital applications are traditionally applied to maximise customer experience of modern and convenience, yet the innovative techniques of service delivery can also delight customer experience in other aspects. The innovative service clues can be perceived before, during and after the service transactions; influenced by operational performance and customers' expectation. Defining innovative attributes of the service operations to promote customer satisfaction and behavioural intentions as well as improving operational effectiveness. Thus, it is important to explore and gain a better understanding of customer positive emotions toward the services that bring them a new and delightful experience.

This paper thematically analyses the content of reviews to demonstrate customer perception of the innovativeness in service operations and provides propositions for further investigation. As demonstrated in the paper, customers perceive the Innovative Humanic Clues through service delivery, communication, personalised service, appearance and problems solving. Clues that related to service staff was found to be the most mentioned in the reviews, and that directly influenced customer perception. The happiness of customers can be influenced by staff emotions which reflected through their appearance and behaviours. The difference of service staff quality in boutique hotels is the nature of caring that gives customers the feeling of family. The caring leads to effective communication between customers and staff for better operational efficiency. The Innovative Mechanic Clues are also important to stimulate customers sensual perception. The configuration of aesthetic of the design, the beauty of nature, detail-focused in food and beverage services, aroma and sound effect to deliver customers the unique feeling of relaxation. The Innovative Functional Clues prefer to the application of technology, unique features of rooms and facilities to optimise the convenience for customers. Defining innovative clues of service operations can lead to favourable behavioural intentions such as returning and recommending.
In terms of theoretical implication, this paper proposes a conceptual model that follows the Service-Dominant Logic school of thought. The school of thought emphasises the importance of innovativeness of intangible values and customer involvement, besides technological innovation, to maximise customer satisfaction and operational efficiency. The study defines innovative clues to contribute to the literature of hospitality, particularly in the aspect of service innovation. The boutique hotel is a sector that concentrates on the delight of warmness, psychology and social interaction rather than standardisation of technology. The study also proposes a conceptual model for further investigation of customer perception toward innovative service operations.

For practical implications, this paper provides a set of detailed innovative service clues that international customers perceived of boutique hotels in Vietnam. Having an appropriate operational strategy to configure these service clues can make it innovative from the perspective of international customers. The paper also proposes the idea that boutique hoteliers should consider to appropriately apply technology to streamline customers' perception of convenience and innovation.

This paper employed qualitative research technique that provides an in-depth analysis of customers' opinions on innovativeness in boutique hotel operations. The paper explored the innovative attributes of service operations that influence customer perception as well as a comprehensive understanding of their attitude towards the services. Further studies should test the propositions with quantitative method or mixed methods to have a multi-perspective assessment and refine the theoretical model. In addition, the findings were taken from a specific hotel concept which is the boutique hotel sector. Future research should test the conceptual model in other innovative service operations to ensure the generalisation of the findings.

\section{REFERENCES}

Ahmad, N, Hemdi, M and Othman, D (2017), Boutique Hotel Attributes and Guest Behavioural Intentions, Journal of Tourism, Hospitality \& Culinary Arts, 9 (2), pp. 257-266.

Ali, F, Kim, WG, Li, J and Jeon, H-M (2018), Make It Delightful: Customers' Experience, Satisfaction and Loyalty in Malaysian Theme Parks, Journal of Destination Marketing \& Management, 7, pp. 1-11.

Ali, F, Ryu, K and Hussain, K (2016), Influence of Experiences on Memories, Satisfaction and Behavioural Intentions - a Study of Creative Tourism, Journal of Travel \& Tourism Marketing 33 (1), pp. 85-100.

Andrews, M (2018), Boutique Hotels Take Southeast Asia by Storm, viewed <https://www.scmp.com/magazines/style/travelfood/special-reports/topics/micebiz/article/2142106/boutique-hotels-take>.

Ariffin, AAM and Maghzi, A (2012), A Preliminary Study on Customer Expectations of Hotel Hospitality: Influences of Personal and Hotel Factors, International Journal of Hospitality Management, 31 (1), pp. 191-198.

Assaker, G, Vinzi, VE and O'Connor, P (2011), Examining the Effect of Novelty Seeking, Satisfaction, and Destination Image on Tourists' Return Pattern: A Two Factor, NonLinear Latent Growth Model, Tourism Management, 32 (4), pp. 890-901.

Bagdare, S (2015), Emotional Determinants of Retail Customer Experience, International Journal of Marketing and Business Communication, 4 (2), pp. 9-16. 
Baron, S, Patterson, A, Warnaby, G and Harris, K (2010), ServiceDominant Logic: Marketing Research Implications and Opportunities, Journal of Customer Behaviour, 9 (3), pp. 253-264.

Barrett, M, Davidson, E, Prabhu, J and Vargo, SL (2015), Service Innovation in the Digital Age: Key Contributions and Future Directions, MIS Quarterly, 39 (1), pp. 135-154.

Bernard, R, Wutich, A and Ryan, G (2017), Analysing Qualitative Data: Systematic Approaches, SAGE Publications, Inc., Thousand Oaks, London, New Deli.

Berry, L, Wall, EA and Carbone, LP (2006), Service Clues and Customer Assessment of the Service Experience- Lessons from Marketing., Academy of Management, 20 (2), pp. 43-57.

Bitner, MJ and Hubbert, AR (1994), Encounter Satisfaction Versus Overall Satisfaction, in RT Rust and RL Oliver (eds), Service Quality: New Directions in Theory and Practice, Sage, Thousand Oaks, CA, pp. 72-94.

Bramble, B (2013), The Distinctive Feeling Theory of Pleasure, Philosophical Studies, 162 (2), pp. 201-217.

Braun, V and Clarke, V (2006), Using Thematic Analysis in Psychology, Qualitative Research in Psychology, 3, pp. 77101.

Brotherton, B and Wood, R (2000), Hospitality and Hospitality Management, in C Lashley and A Morrison (eds), In Search of Hospitality: Theoretical Persepctives and Debates, Butterworth-Heinemann, Oxford.

Carlborg, P, Kindström, D and Kowalkowski, C (2014), The Evolution of Service Innovation Research: A Critical Review and Synthesis, The Service Industries Journal, 34 (5), pp. 373-398.

Cetin, G and Walls, A (2016), Understanding the Customer Experiences from the Perspective of Guests and Hotel Managers: Empirical Findings from Luxury Hotels in Istanbul, Turkey, Journal of Hospitality Marketing \& Management, 25 (4), pp. 395-424.

Chen, J-S, Tsou, H-T and Ching, RKH (2011), Co-Production and Its Effects on Service Innovation, Industrial Marketing Management, 40 (8), pp. 1331-1346.

Chen, SC, Raab, C and Tanford, S (2017), Segmenting Customers by Participation, International Journal of Contemporary Hospitality Management, 29 (5), pp. 1468-1485.

Chen, W-J (2011), Innovation in Hotel Services: Culture and Personality, International Journal of Hospitality Management, 30 (1), pp. 64-72.

Cheng, J-S, Tang, T-W, Shih, H-Y and Wang, T-C (2016), Designing Lifestyle Hotels, International Journal of Hospitality Management, 58, pp. 95-106.

Chevers, D and Spencer, A (2017), Customer Satisfaction in Jamaican Hotels through the Use of Information and Communication Technology, Worldwide Hospitality and Tourism Themes, 9 (1), pp. 70-85.

Chua, B-L, Jin, N, Lee, S and Goh, B (2014), Influence of Mechanic, Functional, and Humanic Clues on Customers' Experiential Values and Behavioral Intentions in Full-Service Restaurants, Journal of Foodservice Business Research, 17 (2), pp. 67-84

Dinçer, MZ and Alrawadieh, Z (2017), Negative Word of Mouse in the Hotel Industry: A Content Analysis of Online Reviews on Luxury Hotels in Jordan, Journal of Hospitality Marketing \& Management, 26 (8), pp. 785-804.

Droege, H, Baron, S, Hildebrand, D and Heras Forcada, MA (2009), Innovation in Services: Present Findings, and Future Pathways, Journal of Service Management, 20 (2), pp. 131155.

Durst, S, Mention, A and Poutanen, P (2015), Service Innovation and Its Impact: What Do We Know About?, Investigaciones europeas de dirección y economía de la empresa, 21 (2), pp. 65-72.

Elo, S, Kääriäinen, M, Kanste, O, Pölkki, T, Utriainen, K and Kyngäs, H (2014), Qualitative Content Analysis: A Focus on
Trustworthiness, SAGE Open, 4 (1).

Elo, S and Kyngas, H (2007), The Qualitative Content Analysis Process, Journal of Advanced Nursing, 62 (1), pp. 107-115.

EuromonitorInternational (2018), Experience More across the Customer Journey.

Fereday, J and Muir-Cochrance, E (2006), Demonstrating Rigor Using Thematic Analysis a Hybrid Approach of Inductive and Deductive Coding and Theme Development, International Journal of Qualitative Methods, 5 (1), pp. 8092.

Fitzsimmons, JA and Fitzsimmons, MJ (2000), New Service Development: Creating Memorable Experiences, Sage Publications, Thousand Oaks, CA.

Gabriel, AS, Cheshin, A, Moran, CM and van Kleef, GA (2016), Enhancing Emotional Performance and Customer Service through Human Resources Practices: A Systems Perspective, Human Resource Management Review, 26 (1), pp. 14-24.

Gadrey, J, Gallouj, F and Weinstein, O (1995), New Modes of Innovation- How Services Benefit Industry., International Journal of Service Industry Managament, 6 (3), pp. 4-16.

Gallouj, F (2002), Innovation in the Service Economy: The New Wealth of Nations, Edward Elgar Publishing.

Gallouj, F and Savona, M (2009), Innovation in Services: A Review of the Debate and a Research Agenda., Journal of Evolutionary Economics, 19 (2), p. 149.

García-Buades, E, Martínez-Tur, V, Ortiz-Bonnín, S and Peiró, JM (2016), Engaged Teams Deliver Better Service Performance in Innovation Climates, European Journal of Work and Organizational Psychology, 25 (4), pp. 597-612.

Garg, A and Amelia, M (2016), Service Clues' Influence on Customers' Dining Experience in Fine Dining Restaurants, Asia-Pacific Journal of Innovation in Hospitality and Tourism, 5 (1), pp. 91-109.

Gilmore, JH and Pine II, JB (2002), Differentiating Hospitality Operations Via Experiences. Why Selling Services Is Not Enough, Cornell Hotel and Restaurant Administration Quarterly, pp. 87-96.

Gustafsson, A, Verma, R, Kristensson, P and Witell, L (2012), Customer Co-Creation in Service Innovation: A Matter of Communication?, Journal of Service Management, 23 (3), pp. 311-327.

Haddad, E, Hallak, R and Assaker, G (2015), Price Fairness Perceptions and Hotel Customers' Behavioural Intentions, Journal of Vacation Marketing, 1, p. 15.

Hemmington, N (2007), From Service to Experience: Understanding and Defining the Hospitality Business, The Service Industries Journal, 27 (6), pp. 747-755.

Henderson, JC (2011), Hip Heritage: The Boutique Hotel Business in Singapore, Tourism and Hospitality Research, 11 (3), pp. 217-223.

Hertog, PD, Gallouj, F and Segers, J (2011), Measuring Innovation in a 'Low-Tech' Service Industry: The Case of the Dutch Hospitality Industry, The Service Industries Journal, 31 (9), pp. 1429-1449.

Hertog, PD, Stauss, B, Van Der Aa, W and De Jong, MW (2010), Capabilities for Managing Service Innovation: Towards a Conceptual Framework, Journal of Service Management, 21 (4), pp. 490-514.

Hipp, C and Grupp, H (2005), Innovation in the Service Sector: The Demand for Service-Specific Innovation Measurement Concepts and Typologies, Research policy, 34 (4), pp. 517 535.

Horng, J-S, Liu, C-H, Chou, S-F, Tsai, C-Y and Chung, Y-C (2017), From Innovation to Sustainability: Sustainability Innovations of Eco-Friendly Hotels in Taiwan, International Journal of Hospitality Management, 63, pp. 44-52.

Hussein, AS, Hapsari, RDV and Yulianti, I (2018), Experience Quality and Hotel Boutique Customer Loyalty: Mediating Role of Hotel Image and Perceived Value, Journal of Quality Assurance in Hospitality \& Tourism, 19 (4), pp. 442-459. 
Javadi, M and Zarea, K (2016), Understanding Thematic Analysis and Its Pitfall, Journal of Client Care, 1 (1), pp. 34-40.

Jones, DL, Day, J and Quadri-Felitti, D (2013), Emerging Definitions of Boutique and Lifestyle Hotels: A Delphi Study, Journal of Travel \& Tourism Marketing, 30 (7), pp. 715-731.

Jones, MA and Suh, J (2000), Transaction-Specific Satisfaction and Overall Satisfaction: An Empirical Analysis, Journal of Services Marketing, 14 (2), pp. 147-159.

Kattara, HS and El-Said, OA (2014), Customers' Preferences for New Technology-Based Self-Services Versus Human Interaction Services in Hotels, Tourism and Hospitality Research, 13 (2), pp. 67-82.

Khan, M and Khan, MA (2009), How Technological Innovations Extend Services Outreach to Customers, International Journal of Contemporary Hospitality Management, 21 (5), pp. 509-522.

Kim, E, Tang, L and Bosselman, R (2018), Measuring Customer Perceptions of Restaurant Innovativeness: Developing and Validating a Scale, International Journal of Hospitality Management, 74, pp. 85-98.

Kindström, D and Kowalkowski, C (2014), Service Innovation in Product-Centric Firms: A Multidimensional Business Model Perspective, Journal of Business \& Industrial Marketing, 29 (2), pp. 96-111.

Kuo, C-M, Chen, L-C and Tseng, C-Y (2017), Investigating an Innovative Service with Hospitality Robots, International Journal of Contemporary Hospitality Management, 29 (5), pp. 1305-1321.

Lashley, C (2008), Studying Hospitality: Insights from Social Sciences, Scandinavian Journal of Hospitality and Tourism, 8 (1), pp. 69-84

Lashley, C (2015), Hospitality and Hospitableness, Research in Hospitality Management, 5 (1), pp. 1-7.

Lee, J, Kao, H-A and Yang, S (2014), Service Innovation and Smart Analytics for Industry 4.0 and Big Data Environment, Procedia CIRP, 16, pp. 3-8.

Lee, W-H and Cheng, C-C (2018), Less Is More: A New Insight for Measuring Service Quality of Green Hotels, International Journal of Hospitality Management, 68, pp. 32-40.

Lusch, RF and Nambisan, S (2015), Service Innovation: A Service Dominant Logic Perspective, MIS Quarterly, 39 (1), pp. 155175.

Lye, V (2017), Independent Hotels Charge into Asia, Play Major Factor in Supply Growth, viewed $<$ https://www.duettocloud.com/library/independent-hotelscharge-asia-play-major-factor-supply-growth>.

Lynch, P, Molz, JG, McIntosh, A, Lugosi, P and Lashley, C (2011), Theorizing Hospitality, Hospitality \& Society, 1 (1), pp. 3-24.

McIntosh, AJ and Siggs, A (2005), An Exploration of the Experiential Nature of Boutique Accommodation, Journal of Travel Research, 44 (1), pp. 74-81.

McNeill, D (2008), The Hotel and the City, Progress in Human Geography, 32, pp. 383-398.

Moon, H, Park, J and Kim, S (2015), The Importance of an Innovative Product Design on Customer Behavior: Development and Validation of a Scale, Journal of Product Innovation Management, 32 (2), pp. 224-232.

Morrar, R (2014), Innovation in Services- a Literature Review., Technology Innovation Management Review, 4 (4), pp. 6-14.

Mun Lim, W and Endean, M (2009), Elucidating the Aesthetic and Operational Characteristics of Uk Boutique Hotels, International Journal of Contemporary Hospitality Management, 21 (1), pp. 38-51.

Murray, SB, Griffiths, S, Hazery, L, Shen, T, Wooldridge, T and Mond, JM (2016), Go Big or Go Home: A Thematic Content Analysis of Pro-Muscularity Websites, Body Image, 16, pp. 17-20.

Netzer, O, Feldman, R, Goldenberg, J and Fresko, M (2012), Mine Your Own Business Market-Structure Surveillance through Text Mining, Marketing Science, 31 (3), pp. 521-543.
Nguyen, H, Groth, M, Walsh, G and Hennig-Thurau, T (2014), The Impact of Service Scripts on Customer Citizenship Behaviour and the Moderating Role of Employee Customer Orientation, Psychology and Marketing, 31 (12), pp. 1096-1109.

Noble, LW (2018), Is There Room for Capsule Hotels in Singapore's Crowded Hotel Market?, viewed $<$ https://sbr.com.sg/hotels-tourism/news/there-roomcapsule-hotels-in-singapores-crowded-hotel-market>.

Oliver, R (1977), Effect of Expectation and Disconfirmation on Postexposure Product Evaluations- an Alternative Interpretation., Journal of Applied Psychology, 62 (4), pp. 480-486.

Ordanini, A and Parasuraman, A (2010), Service Innovation Viewed through a Service-Dominant Logic Lens: A Conceptual Framework and Empirical Analysis, Journal of Service Research, 14 (1), pp. 3-23.

Ordanini, A, Parasuraman, A and Rubera, G (2014), When the Recipe Is More Important Than the Ingredients, Journal of Service Research, 17 (2), pp. 134-149.

Ottenbacher, M and Gnoth, J (2005), How to Develop Successful Hospitality Innovation, Cornell Hotel and Restaurant Administration Quarterly, 46 (2), pp. 205-222.

Ottenbacher, M, Harrington, R and Parsa, HG (2009), Defining the Hospitality Discipline: A Discussion of Pedagogical and Research Implications, Journal of Hospitality \& Tourism Research, 33 (3), pp. 263-283.

Ottenbacher, M, Shaw, V and Lockwood, A (2006), An Investigation of the Factors Affecting Innovation Performance in Chain and Independent Hotels, Journal of Quality Assurance in Hospitality \& Tourism, 6 (3-4), pp. 113 128.

Ottenbacher, MC (2007), Innovation Management in the Hospitality Industry: Different Strategies for Achieving Success, Journal of Hospitality \& Tourism Research, 31 (4), pp. 431-454.

Parasuraman, A, Zeithaml, V and Berry, L (1990), Delivering Quality Service: Balancing Customer Perceptions and Expectations, Free Press, New York.

Rogers, EM (2010), Diffusion of Innovations, 4th edn, Simon and Schuster.

Rogerson, JM (2010), The Boutique Hotel Industry in South Africa: Definition, Scope, and Organization, Urban Forum, 21 (4), pp. $425-439$.

Rosenbaum, MS and Wong, IA (2015), If You Install It, Will They Use It? Understanding Why Hospitality Customers Take "Technological Pauses" from Self-Service Technology, Journal of Business Research, 68, pp. 1862-1868.

Shahi, S and Goswami, P (2018), Raising the Standards of Hospitality through the Role of Innovation and Culture. A Case Study on Hotel Justa, The Business and Management Review, 9 (3), pp. 352-356.

Skålén, P, Gummerus, J, von Koskull, C and Magnusson, PR (2015), Exploring Value Propositions and Service Innovation: A Service-Dominant Logic Study, Journal of the Academy of Marketing Science, 43 (2), pp. 137-158.

Slattery, P (2002), Finding the Hospitality Industry., Journal of Hospitality, Leisure, Sport and Tourism Education, 1 (1), pp. 19-28.

Snyder, H, Witell, L, Gustafsson, A, Fombelle, P and Kristensson, P (2016), Identifying Categories of Service Innovation: A Review and Synthesis of the Literature, Journal of Business Research, 69 (7), pp. 2401-2408.

Stanko, MA, Molina-Castillo, F-J and Harmancioglu, N (2014), It Won't Fit! For Innovative Products, Sometimes That's Forthe Best, Journal of Product Innovation Management, 32 (1), pp. 122-137.

Telfer, E (2000), The Philosophy of Hospitableness, in C Lashley and A Morrison (eds), In Search of Hospitality: Theoretical Perspectives and Debates, Butterworth-Heinemann, Oxford.

Toivonen, M and Tuominen, T (2009), Emergence of Innovations 
in Services, The Service Industries Journal, 29 (7), pp. 887902.

Torres, EN, Fu, X and Lehto, X (2014), Examining Key Drivers of Customer Delight in a Hotel Experience: A Cross-Cultural Perspective, International Journal of Hospitality Management, 36, pp. 255-262.

Torres, EN and Kline, S (2013), From Customer Satisfaction to Customer Delight, International Journal of Contemporary Hospitality Management, 25 (5), pp. 642-659.

Truong, N, Nisar, T, Knox, D and Prabhakar, G (2017), The Influences of Cleanliness and Employee Attributes on Perceived Service Quality in Restaurants in a Developing Country, International Journal of Culture, Tourism and Hospitality Research, 11 (4), pp. 608-627.

Tsai, Y-H, Wu, C-T and Chen, S-L (2015), Hotel Choice Criteria by Business and Leisure Travelers, International Journal of Organizational Innovation, 17 (4), pp. 158-164.

Vaismoradi, M, Turunen, H and Bondas, T (2013), Content Analysis and Thematic Analysis: Implications for Conducting a Qualitative Descriptive Study, Nursing Health Sciences, 15 (3), pp. 398-405.

Van Hartesvelt, M (2006), Building a Better Boutique Hotel, Lodging Hospitality, 62 (14), pp. 32-44.

Vargo, SL and Lusch, RF (2007), Service-Dominant Logic: Continuing the Evolution, Journal of the Academy of Marketing Science, 36 (1), pp. 1-10.

Vo Thanh, T and Kirova, V (2018), Wine Tourism Experience: A Netnography Study, Journal of Business Research, 83, pp. 30-37.

Walls, AR (2013), A Cross-Sectional Examination of Hotel Consumer Experience and Relative Effects on Consumer Values, International Journal of Hospitality Management, 32, pp. 179-192.

Wang, T-C, Tang, T-W and Cheng, J-S (2018), Art-Oriented Model of Hotel Service Innovation, International Journal of Contemporary Hospitality Management, 30 (1), pp. 160-177.
Wang, Y-C and Beise-Zee, R (2013), Preencounter Affective States of Business Travelers and Service Responses, Journal of Hospitality Marketing \& Management, 22 (6), pp. 634-655.

Wang, Y-C, Luo, C-C and Tai, Y-F (2017), Implementation of Delightful Services: From the Perspective of Frontline Service Employees, Journal of Hospitality and Tourism Management, 31, pp. 90-104.

Whalen, EA (2018), Understanding a Shifting Methodology: A Content Analysis of the Use of Netnography in Hospitlaity and Tourism Research, International Journal of Contemporary Hospitality Management, 30 (11), pp. 34233441.

Winnick, R (2011), Redefining the Boutique Hotel Concept, thesis, Corcoran College of Art+ Design.

Witell, L, Snyder, H, Gustafsson, A, Fombelle, P and Kristensson, P (2016), Defining Service Innovation: A Review and Synthesis, Journal of Business Research, 69 (8), pp. $2863-$ 2872.

Wuenderlich, NV, Heinonen, K, Ostrom, AL, Patricio, L, Sousa, R, Voss, C and Lemmink, JGAM (2015), "Futurizing" Smart Service: Implications for Service Researchers and Managers, Journal of Services Marketing, 29 (6/7), pp. 442-447.

$\mathrm{Xu}, \mathrm{X}$ and Li, Y (2016), The Antecedents of Customer Satisfaction and Dissatisfaction toward Various Types of Hotels Text Mining Approach, International Journal of Hospitality Management, 55 (57-69).

Zamawe, FC (2015), The Implication of Using Nvivo Software in Qualitative Data Analysis: Evidence-Based Reflections, Malawi Medical Journal, 27 (1).

Zeithaml, VA, Parasuraman, A and Berry, LL (1990), Delivering Quality Service: Balancing Customer Perceptions and Expectations, Simon and Schuster, New York.

Zhang, Z and Hou, Y (2017), The Effect of Perceived Risk on Information Search for Innovative Products and Services the Moderating Role of Innate Consumer Innovativeness, Journal of Consumer Marketing, 34 (3), pp. 241-254.

Ms. Ngan Tuyet Truong is a PhD Candidate in the School of Business and Management, RMIT University. She takes research on Service Innovation, Operation Management, Tourism and Hospitality, Customer Satisfaction, Customer Behaviours. Her first paper, published in 2017, discussed customer satisfaction of restaurant service quality in Vietnam.

Dr. Duy Dang-Pham is an Assistant Professor of Information Technology in the School of Science and Technology, RMIT University, where he obtained his Ph.D. in Business Information Systems. His research focuses on social network analysis, behavioural information security, business and learning analytics, digital business and innovation, and information technology management. Dr. Dang-Pham has a track record of securing research funding totally up to US\$ 71,000 in 2018.

Dr. Robert McClelland is an Associate Professor and the Head of Management Department, RMIT University. Dr. Robert McClelland undertakes research on Tourism and Hospitality, Higher Education, Statistics applied to Health and Sport. His current projects are Managing Health Interventions in Society, Supporting Student Learning via technology and Global Value Chain, Corruption and Ethics.

Dr. Mathews Nkhoma is a Professor and the Head of Business and Management School, RMIT University. Dr. Mathews Nkhoma undertakes research on Business Information Systems, Computer Communications, Computer Security and Reliability. 